Women of the Praia 



\title{
Women of the Praia
}

\author{
WORK AND LIVES IN A \\ PORTUGUESE COASTAL COMMUNITY
}

Sally Cole

PRINCETON UNIVERSITY PRESS

PRINCETON, NEW JERSEY 
Copyright 1991 by Princeton University Press

Published by Princeton University Press, 41 William Street,

Princeton, New Jersey 08540

In the United Kingdom: Princeton University Press, Chichester, West Sussex

All Rights Reserved

Library of Congress Cataloging-in-Publication Data

Cole, Sally Cooper, $1951-$

Women of the praia : work and lives in a Portuguese coastal community / Sally Cole.

p. $\mathrm{cm}$.

Includes bibliographical references and index.

ISBN 0-691-09464-0 -- ISBN 0-691-02862-1 (pbk.)

1. Women fishers--Portugal--Vila Chă (Porto)--Case studies.

2. Women fish trade workers--Portugal--Vila Chã (Porto)--Case studies. 3. Women--Portugal--Vila Chā (Porto)--Social conditions.

4. Women--Portugal--Vila Chã (Porto)--Economic conditions.

I. Title.

HD6073.F652P83 1991

91-2359

331.4'8392'0946915--dc20

This book has been composed in Linotron Primer

Princeton University Press books are printed on acid-free paper and meet the guidelines for permanence and durability of the Committee on Production Guidelines for Book Longevity of the Council on Library Resources

Printed in the United States of America

$$
\begin{array}{lllll}
7 & 9 & 10 & 8 & 6
\end{array}
$$

ISBN-13: 978-(0-691-02862-0

ISBN-10: 0-691-02862-1 
For Michael,

Samuel,

and Isabella 
